J. H. SAttler, M. FuChS, F. G. Mutti, B. GRischeK, P. Engel, J. PFEFFER, J. M. WOODLEY, W. KROUTIL* (UNIVERSITY OF GRAZ AND AUSTRIAN CENTRE OF INDUSTRIAL BIOTECHNOLOGY, GRAZ, AUSTRIA; EVONIK INDUSTRIES, MARL, GERMANY; TECHNICAL UNIVERSITY OF DENMARK, LYNGBY, DENMARK) Introducing an In Situ Capping Strategy in Systems Biocatalysis To Access 6-Aminohexanoic acid Angew. Chem. Int. Ed. 2014, 53, 14153-14157.

\section{A One-Pot Biocatalytic Sequence to 6-Aminohexanoic Acid}
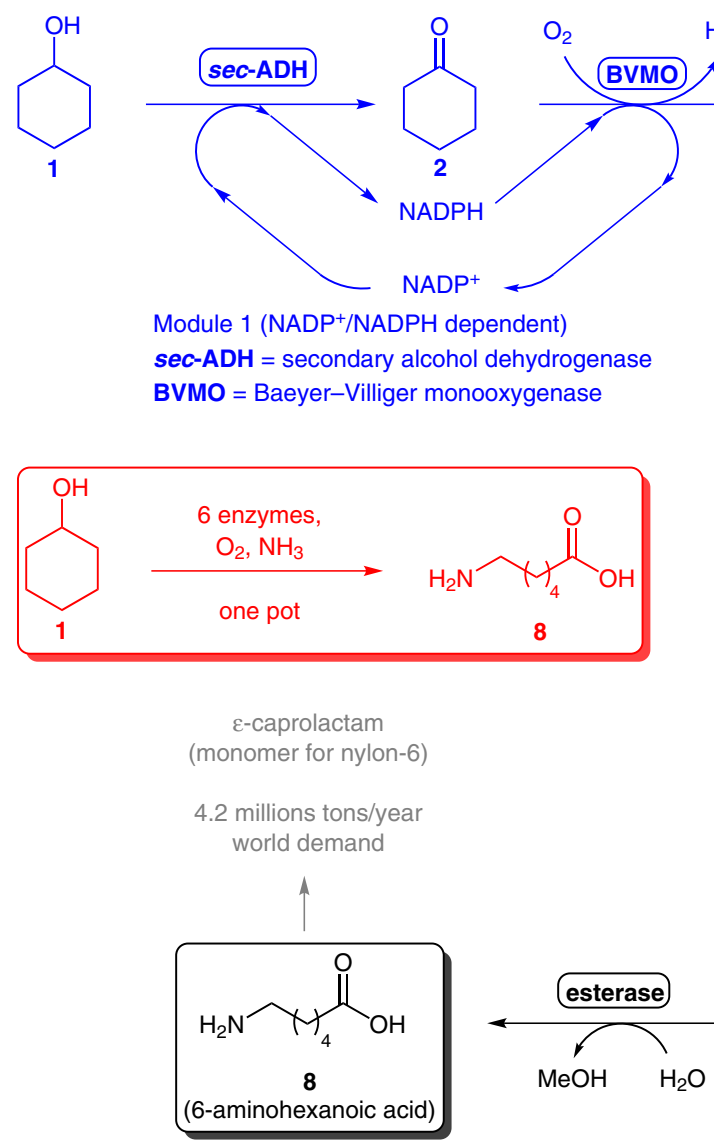

up to $24 \%$ conversion from 1 up to $75 \%$ conversion from 3

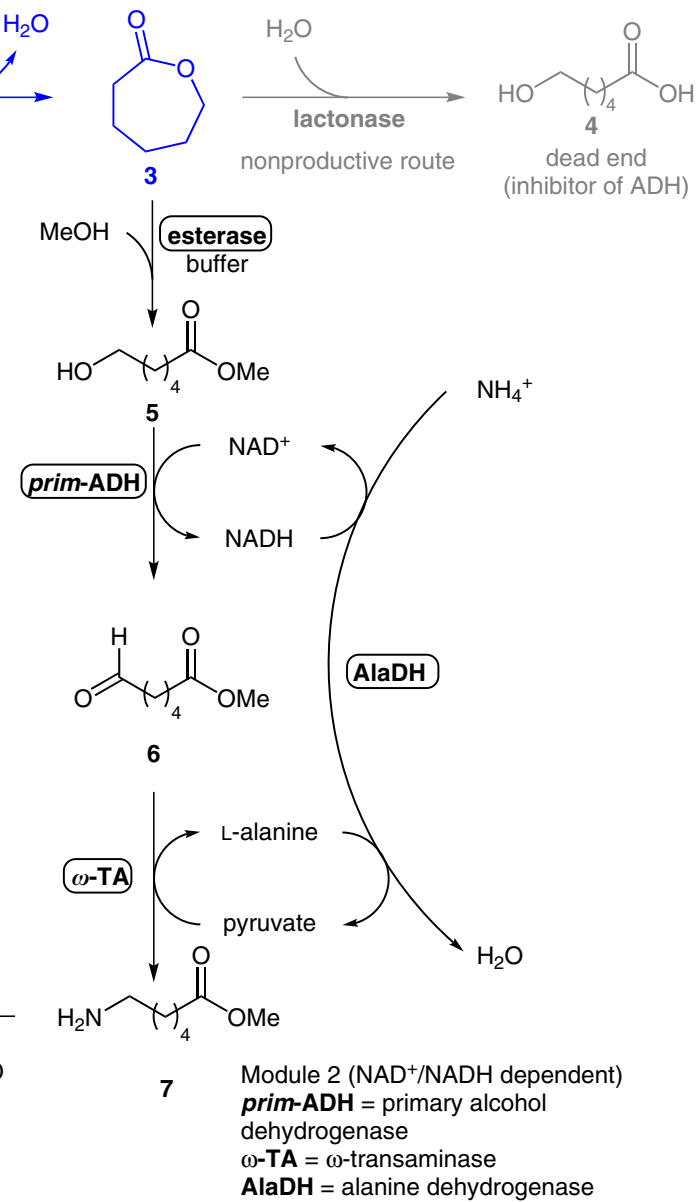

Gategory

Organo- and Biocatalysis

\section{Key words}

aminohexanoic acid

nylon

capping strategy

enzyme catalysis

SYNFACCand
Significance: Kroutil and co-workers report two sequential biocatalytic self-sufficient redox modules (the co-factor required for a step is regenerated in successive step) for the synthesis of 6-aminohexanoic acid, the precursor of $\varepsilon$-caprolactam (the monomer of nylon-6). The process affords the desired product $\mathbf{8}$ from $\mathbf{1}$ (up to 24\% conversion) or $\mathbf{3}$ (up to $75 \%$ conversion). The key of the system is to circumvent the formation of $\mathbf{4}$ via in situ capping (esterification).

SYNFACTS Contributors: Benjamin List, Gabriele Pupo Synfacts 2015, 11(1), 0087 Published online: 15.12.2014 Dol: 10.1055/s-0034-1379622; Reg-No.: B12514SF
Comment: The production of $\varepsilon$-caprolactam is one of the largest industrial processes in the world, and therefore, new environmentally friendly synthetic sequences are continuously required. The authors design an unprecedented sequence (two independent modules) in which $\mathbf{8}$ is obtained from cheap starting materials ( $\mathbf{1}$ or $\mathbf{3}$ ) via the meth$\mathrm{yl}$ ester key intermediate $\mathbf{5}$, at the sole expense of $\mathrm{O}_{2}$ and $\mathrm{NH}_{3}$. 